\title{
The Evolution of Articulators - Part II
}

\author{
Navneet Kaur Mann', Neeta Pasricha', Kavipal Singh², Navjot Singh Mann ${ }^{3}$ \\ ${ }^{1}$ National Dental College and Hospital, Derabassi, Punjab, India; \\ ${ }^{2}$ Sri Guru Ram Das Institute Of Dental Sciences And Research, Amritsar, Punjab, India; \\ ${ }^{3}$ Conservative Dentistry and Endodontics, National Dental College and Hospital, Derabassi, Punjab, India
}

\begin{abstract}
SUMMARY
Articulators are instruments that aimed to reproduce the range of jaw movements. The first instrument designs were attempts to duplicate anatomic relations or reproduce functional movements of the anatomy. They were able to preserve centric position only. More sophisticated articulating instruments evolved as more was learned about the anatomy, mandibular movements, and mechanical principles. Over time, interest for articulators progressed. Articulators became adjustable, and they attempted to reproduce jaw movements of each patient by reproducing the anatomy of temporomandibular joints (TMJ's) and related structures. Part I of the article has discussed evolution of articulators beginning from the $18^{\text {th }}$ century till 1940. A history of articulators from 1940 till today is discussed in the present article. Keywords: articulators; instruments; cast; temporomandibular joints; hinge
\end{abstract}

In continuation on the history of articulators part I, where the evolution of articulators beginning from the $16^{\text {th }}$ century was described, the current article discusses the historical aspect of articulators since 1940.

Articulators introduced since 1940 range from the type that maintains a prescribed position, to fully adjustable articulators [1]. By the turn of the 20th century, several investigators have examined the nature of mandibular movements. Therefore, development of articulators has reflected newly discovered or rediscovered principles [2]. Historically, some aspects of jaw movements have been easy to duplicate mechanically on an articulator (hinge movement, relation of the casts to the hinge and inclination of the condylar path). Consequently these features appeared first on the instruments. Other movements have been more difficult to reproduce mechanically, such as Bennett movement in three dimensions, the timing of the Bennett movement, the exact curvature of the condylar path and intercondylar distance. The problems involved in duplicating these movements have been solved by modern instrument design. Through the history, some articulators have been modified and some have not been accepted by the profession and disapeared.

The current article has aimed to describe articulators introduced into the dental practice since 1940 till the present.

An electronic search was performed across the three databases (Science Direct, PubMed and Google Scholar) for relevant citations. Keywords such as articulators, history, and early articulators were used alone or in combination for the search. The option of "related articles" was also utilized. Finally, a search of review articles was performed and the most relevant papers pertaining to the history of articulators were selected.

\section{The Modified Stephen Articulator}

The Stephen articulator (Figure 1), as modified in 1940, is a simple hinge joint articulator that has fixed condylar path of 30 degrees. It is similar in design to the 1921 model, except that the upper and lower mounting arms on this model are longer. An adjustable setscrew in the posterior region holds the upper and lower members in the fixed vertical position [1].

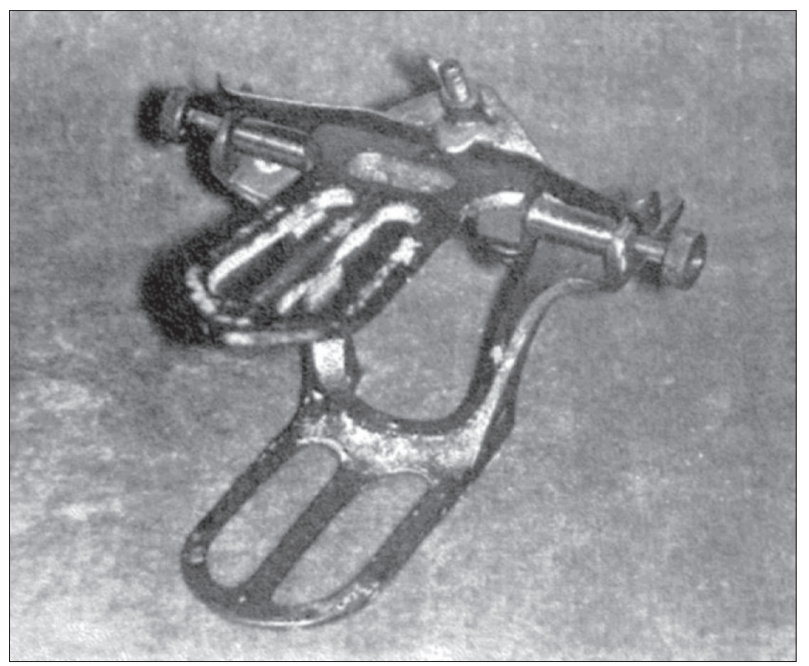

Figure 1. Modified Stephen Articulator ${ }^{[1]}$

Slika 1. Modifikovani artikulator Stephen ${ }^{[1]}$

\section{The Stephen Articulator Model P}

The additional features of the Stephen articulator Model $P$ are incisal pin and vertical height adjustment. Another 
version of this articulator was manufactured to include a fixed 10 degree incisal guidance [1].

\section{The Fournet Articulator}

The Fournet articulator (Figure 2) was developed around 1940 and distributed by the Dentists' Supply Co. of New York. The Fournet articulator is one-dimension articulator that has no lateral movement. The maxillary cast is positioned horizontally by (1) the two maxillary central incisors, which are oriented aesthetically and rest on Spee curve template anteriorly, and (2) the Cook mounting jig, which fits into the depth of the hamular notch and orients the casts posteriorly [1].

\section{The Johnson-Oglesby Articulators}

The Johnson-Oglesby articulator was developed around 1950. It is small, nonadjustable, flexible articulator. The Johnson-Oglesby instrument had limited use, and restorations produced using it sometimes required major adjustments intraorally [1].

\section{The Coble Articulator}

The Coble articulator was developed around 1950. by Lucian G. Coble. The Coble articulator maintains centric relation and vertical dimension but does not allow functional movements. It is a hinge articulator in which the maxillary cast is mounted with a mounting jig that corresponds to the occlusal plane. The mandibular cast is positioned with an interocclusal record [1].

\section{The Galetti Articulator}

The Galetti articulator (Figure 3) was first manufactured about 1950. in Italy. It was advertised in this country in the early 1960's and distributed by John O. Luongo. In this articulator, each cast was held mechanically without plaster by two fixed posts anteriorly and one adjustable post posteriorly to each member. The upper member was adjustable by an extendable arm and a universal ball-andsocket joint to achieve the desired relationship of the maxillary to the mandibular cast, which permitted rapid cast mounting. This articulator had fixed condylar path and a vertical stop that was in the posterior region. It did not accept a face-bow [1].

\section{The Pankey-Mann Articulator}

The Pankey-Mann articulator (Figure 4) was developed in 1955. by Lindsey De Pankey and Arvin W. Mann. This articulator consists of a base that holds a platform for the mandibular cast and a vertical post containing two movable assemblies. The first assembly was made up of a horizontal rod that supports the face bow frame and also has centers of rotation for measuring and cutting calibres. A second movable assembly hold the mounted maxillary cast. By using the Pankey-Mann face bow to mount the mandibular cast, and cutting dividers to establish an oc-

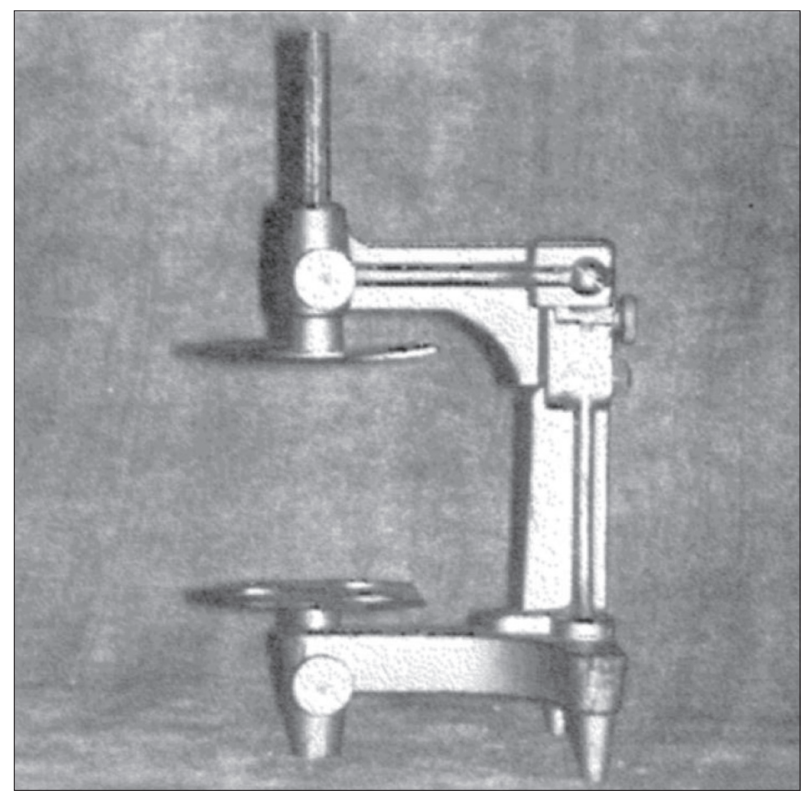

Figure 2. The Fournet Articulator ${ }^{[1]}$

Slika 2. Artikulator Fournet ${ }^{[1]}$

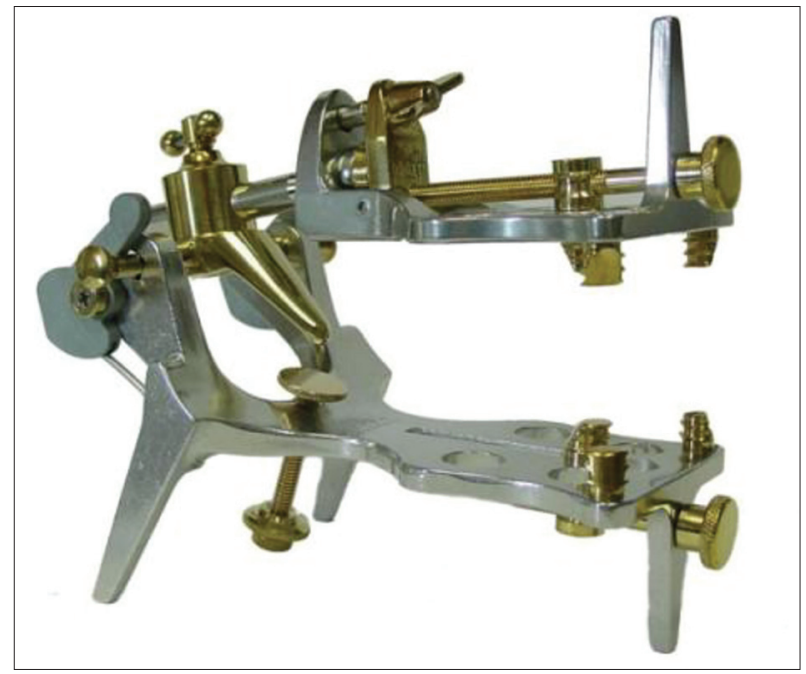

Figure 3. The Galetti Articulator ${ }^{[1]}$

Slika 3. Artikulator Galetti ${ }^{[1]}$

clusal plane in the mandibular teeth based on the spherical theory, the entire occlusal plane was engineered before tooth preparation is initiated [1].

\section{The Stuart Articulator}

The Stuart articulator (Figure 5) was developed by Charles E. Stuart in 1955. It was a fully adjustable articulator. The upper member of the articulator had two sets of cams posteriorly on each side that guide truncated spheres located on the lower member. The movable outer cam and sphere on each side controlled all condylar movements except the angle and timing of the Bennett movement, which were controlled by the inner cam and sphere. The articulator settings were programmed using pantographic tracings from the patient [1]. 


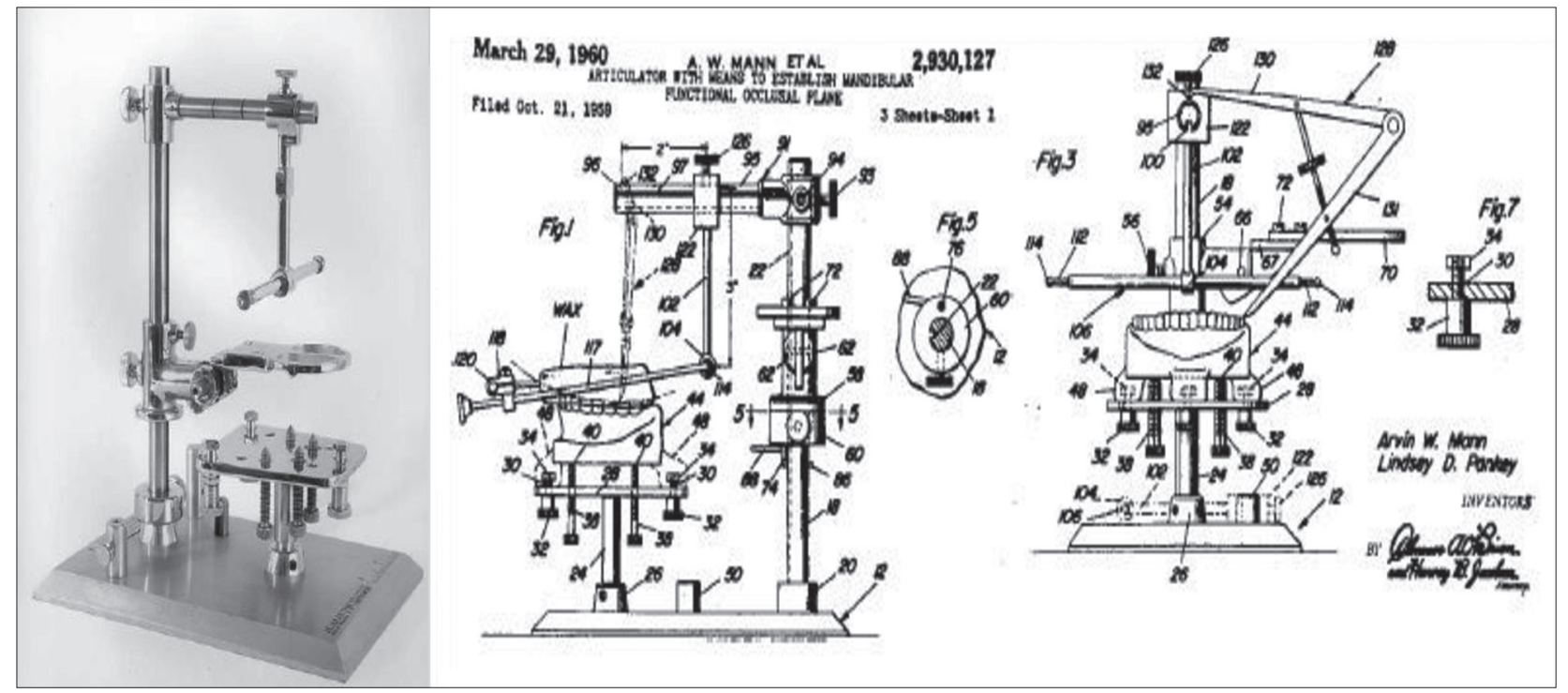

Figure 4. The Pankey-Mann Articulator ${ }^{[1]}$

Slika 4. Artikulator Pankey-Mann ${ }^{[1]}$

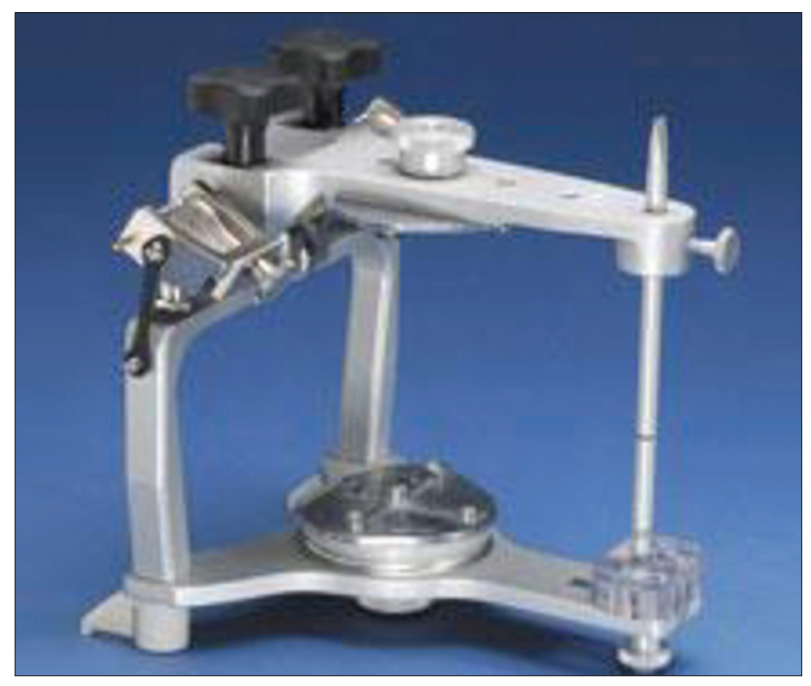

Figure 5. The Stuart Articulator ${ }^{[1]}$ Slika 5. Artikulator Stuart ${ }^{[1]}$

\section{The Hanau Model H2 Series}

The Hanau Model 96 H2 came out in 1958. The principal feature of this articulator was an increased distance between the upper and lower members from $95 \mathrm{~mm}$ to approximately $110 \mathrm{~mm}$. In addition, the orbital indicator was added to the upper member. The H2-XPR, which is one of the models of the $\mathrm{H} 2$ series, was introduced in 1958. It had features identical to those of other models in this series, but in addition, it had extendable condylar shafts and retrusive-protrusive adjustment in the condylar element. Some other models of the $\mathrm{H} 2$ series are:

Model H2-O, with orbital indicator attachment;

Model H2-X, with extendable condylar shafts;

Model H2-PR, with calibrated adjustments to protrude or retrude condylar balls up to $3 \mathrm{~mm}$.

An adaptation of the Hanau Model H110 articulator, which uses a 0.75 inch lucite shim to increase the condylar post height, was described by Elinchbaugh. He also described the fabrication of a 0.75 inch lucite orbital point

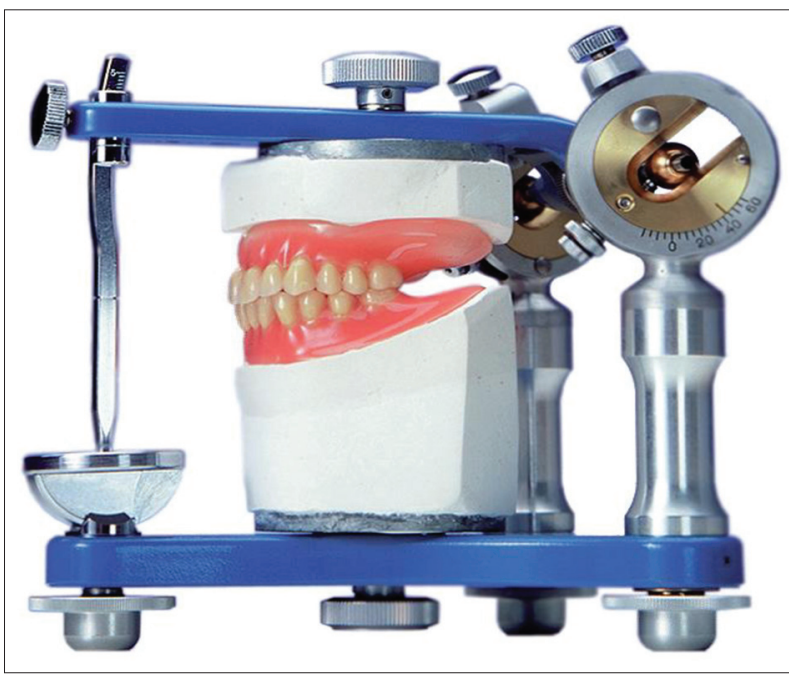

Figure 6. The Dentatus Articulator ${ }^{[1]}$

Slika 6. Artikulator Dentatus ${ }^{[1]}$

guide plane that provided an anterior point of reference level with the condylar axis. This adaptation made the Model $\mathrm{H}$ is equivalent to some models of the $\mathrm{H} 2$ series [1].

\section{The Dentatus ARL Articulator}

The Dentatus ARL articulator (Figure 6) was first manufactured by A.B.Dentatus of Stockholm, Sweden in 1958. It was a semiadjustable, shaft type articulator with a straight condylar path and a fixed intercondylar distance. In mechanical principle and design it was similar to the Hanau $\mathrm{H} 2$ articulator. An adjustable positioning mechanism on the upper member allowed the use of a block that standardizes upper member to lower member, and transfer of casts from one to another articulator while the same relationship was maintained. The Dentatus ARL was a rigid, durable instrument with a curved incisal guide pin. Extendable condylar shafts enabled receiving a hinge axis face-bow. The Bennett movement was calculated from the Hanau's formula, and rotating the condylar post up to 40 
degrees regulated it. As with the Hanau articulators, the size of Bennett movement was controlable, but not the timing or direction [1].

\section{The Improved New Simplex Articulator}

The Improved New Simplex Articulator (Figure 7) was distributed by the Dentists' Supply Co. of New York in 1960. This is an updated version of the Gysi Simplex articulator. It used average movements. The condylar inclination was 30 degrees, with a Bennett movement of 7.5 degrees. The incisal guide table was adjustable from 0 to 30 degrees to accommodate various amounts of vertical overlap of the teeth for each patient. It had model-locking pins to secure the maxillary and mandibular casts in place. A mounting jig, which doubles as an occlusal plane table, was used for arbitrarily mounting the maxillary cast [1].

\section{The Verticulator}

The Verticulator was developed by William Windish in 1960. The Verticulator consisted of two rigid members that separate and close only linearly in vertical dimension. It had a positive stop that locked in its closed position. Another model was introduced in 1962, which was able to accept full arch casts [1].

\section{The Ney Articulator}

The Ney articulator (Figure 8) was designed by Anthony J. De Pietro in 1962. It is an arcon instrument with no locking device between the upper and lower members for centric position. The condylar elements can be set to varying intercondylar distances. When the metal condylar elements do not follow or duplicate pantographic tracings, more precise duplication is possible with custom ground plastic inserts. A plastic incisal guide table, or a metal incisal guide table that has a provision for making a region of freedom centric position can be used [1].

\section{The Hanau Model 130-21 Articulator}

The Hanau University Series or Model 130-21 articulator was designed to be a split-axis instrument. It had a central locking device and a mechanism to keep upper and lower members together. It was adjustable in varying intercondylar distances. The condylar paths and Bennett guide paths were straight. The Bennett guide paths that are located near midline did not allow for immediate side shift. It would accept all positional records but could not duplicate pantographic tracings. The incisal guide pin was designed to compensate for changes in vertical dimension. It was self tripoding in an inverted position [1].

\section{The Whip-Mix Articulator}

The Whip-Mix articulator was developed by Charles E. Stuart in 1964. This was a semiadjustable arcon articulator that had three intercondylar adjustments: small, medium and large. These were selected by means of the accompa-

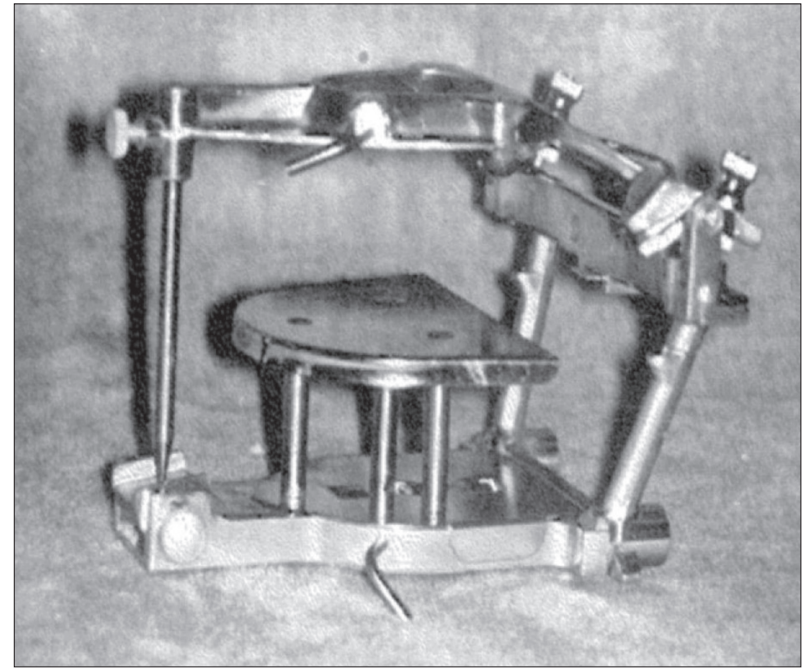

Figure 7. The Improved New Simplex Articulator ${ }^{[1]}$ Slika 7. Poboljšani novi prosti artikulator ${ }^{[1]}$

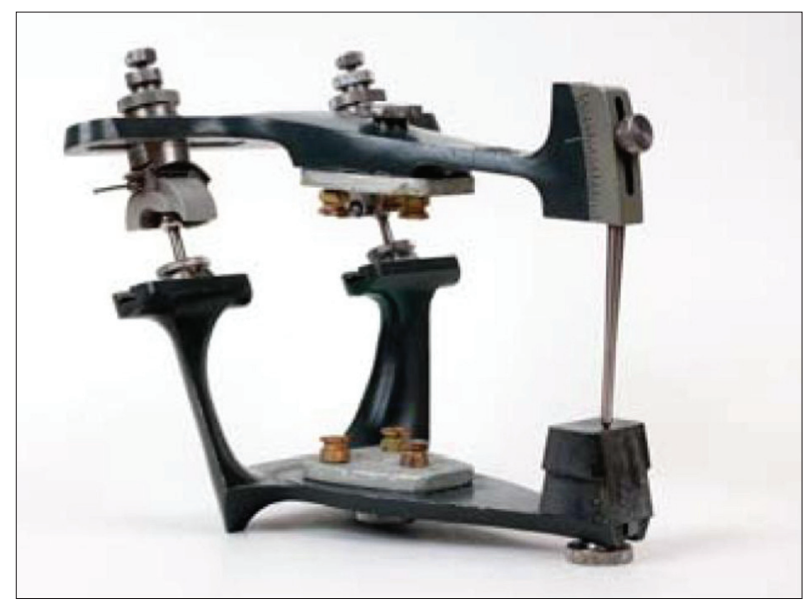

Figure 8. The Ney Articulator ${ }^{[1]}$

Slika 8. Artikulator Ney ${ }^{[1]}$

nying Quick Mount face-bow that uses the external auditory meatus as a posterior landmark. This face-bow had a nasion anterior guide for establishing an anterior point of reference for maxillary cast positioning. The condylar element of the Whip-Mix articulator was adjustable about the vertical and horizontal axis but not the sagittal axis; hence it could not be set to all positional records. The condylar and Bennett guide paths were straight. There was no provision for timing in the Bennett movement. There was no centric position-locking device, and the upper and lower members could not be attached mechanically [1]

\section{The Simulator}

The Simulator (Figure 9) was developed by Ernest R. Granger in 1968. It was a fully adjustable articulator that could be set from pantographic tracings, positional records and other tracings. There were curved condylar paths, but the unique feature of this articulator was the condylar path that rotates inwardly, a broken axis and a mechanical timing element that combine to reproduce mechanically the Bennett movement and Fischer's angle. The Simulator had condylar path locks that could be re- 


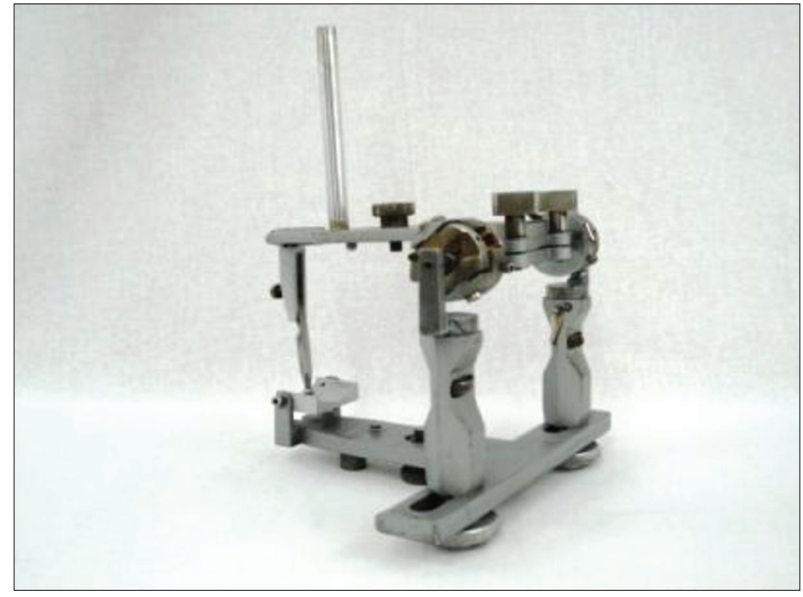

Figure 9. The Simulator ${ }^{[1]}$

Slika 9. Simulator ${ }^{[1]}$

leased so that the upper member could be separated from the lower member. The incisal guide pin was curved [1].

\section{The Denar Model D4A Articulator}

The Denar Model D4A articulator was developed by Niles Guichet in 1963. This articulator was programmed from tracings made with a pneumatically controlled pantograph of the same company, the Denar Corp of Anaheim, California. It was a fully adjustable instrument that used interchangeable condylar guidances that could be adjusted. It had a definite centric lock and had accommodations to hold the casts in an open position. The curved incisal pin assembly could rest on a mechanical or plastic incisal guide table [1].

\section{The Dentatus ARO Articulator}

The Dentatus ARO articulator was manufactured by A.B. Dentatus in 1971. It had all the features of Dentatus ARL plus the unique feature of a movable arm that holds the mandibular cast. The universal joint and the locking device that attaches the movable arm to the base allowed repositioning of the mandibular cast without remounting. The gauge block was used to center the lower member to the upper member, but once the mandibular cast has been repositioned, the articulator or casts could not be interchanged without the aid of centric relation records [1].

\section{The Panadent Articulators}

The Panadent System is the latest approach to dental instrumentation. The Panadent System was based on the premise that it was possible to classify individual condylar movements into groups based on the amount of precurrent side shift. A series of statistically selected three-dimensional analogs of condylar axis motion was developed. The Panadent articulator was introduced in 1978. The current models were introduced in 1983. The major modification in the latest models was the Dynalink Panalock mechanical latch. This mechanism keeps the upper and lower articular frames joined together, yet permits an opening movement of 180 degrees [1].

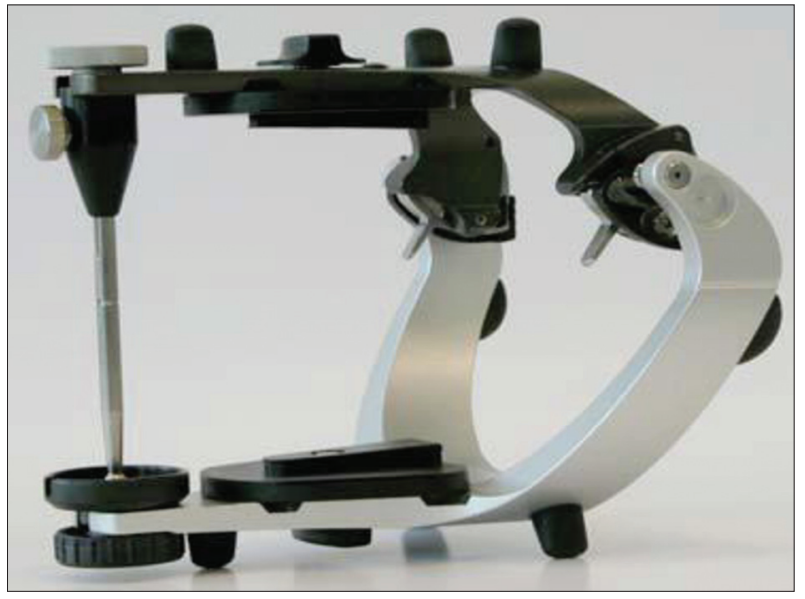

Figure 10. The Protar Articulator ${ }^{[5]}$

Slika 10. Artikulator Protar ${ }^{[1]}$

\section{Recent Advances}

SAM

The company was founded in 1971 by Heinz Mack, a practising dentist, in Munich, Germany. Their anatomically correct and skull related articulator system became known and identified as SAM (School Articulator Munich). These are basically arcon type of articulators. SAM developed a wide variety of articulator models, including SAM SE, SAM 2P, SAM 2PX and SAM 3. These articulators provide accurate functional simulation of mandibular movements $[2,3]$.

\section{The Artex Articulator}

This articulator was developed by GIRRBACH DENTAL GMBH Company and was listed in the FDA on $24^{\text {th }}$ May, 1995. The ARTEX CN, which was the base model, is a non-arcon type average value articulator. The ARTEX CT is partially adjustable average-value articulator in non-Arcon design. Then came the ARTEX CP, which was partially adjustable average-value articulator with super smooth condyle track guide in Arcon design. The latest model was the ARTEX CR, which was fully adjustable average-value articulator in Arcon design. It provides comprehensive adjustment possibilities to reproduce the patient's clearance and movement dynamics [4].

\section{The Protar Articulator}

Developed by the KaVo Company during the begining of this century, the PROTAR articulators (Figure 10) offer good precision, they are cost effective and provide superior handling. Four models are available- the PROTAR, the PROTAR 3, the PROTAR 5, the PROTAR 7, and the latest model is the PROTAR 9. The PROTAR is 6.4 " $\mathrm{H} \mathrm{x}$ 6.6" W x 8" D and weighs $2.5 \mathrm{lbs}$. The Protar 3 has an upper member with curved sagittal and pre-set condylar guidance paths, $\mathrm{a} 45^{\circ}$ horizontal condylar inclination, and a $15^{\circ}$ fixed Bennett angle. The PROTAR 5 has an upper member identical to the one in the Protar 3 with the exception that it has an adjustable Bennett angle and an adjustable horizontal condylar inclination. The PROTAR 
7 has an upper member with adjustable sagittal angle and horizontal condylar paths as well as immediate sideshift and retrusion with an adjustable shift angle. The PROTAR 9 has an upper member identical to that of the Protar 7 with adjustable protrusion, distraction, and retrusion [5].

\section{The Virtual Articulators}

The latest breakthrough in the world of articulators was the introduction of the VIRTUAL articulators in 2003. This system not only simulates the temporo-mandibular joint movements in the modelling software by viewing it on the computer screen, but is also the only system that allows the dental technician to take the measurements of his/her own articulator, to scan it and to add these data to the software database. The articulator dimensions are faithfully saved in the software so as to be able to virtually articulate the models.

\section{CONCLUSION}

The large number and great range in complexity of modern articulators can mislead the dentist into thinking that the choice of a suitable instrument is difficult. However, the choice is greatly simplified if one considers what records can be obtained accurately, what the instrument will be required to do, and the fact that articulator technology is not a substitute for a biological understanding of the masticatory system [6]. An emerging understanding of the neurophysiology of mandibular movements and the influence of several morphological and behavioural considerations led to the notion that each patient is his or her own best articulator. Also, the success or failure of the final restoration is more dependent on the operator of the articulator than on the articulator itself [7].

The Late Carl O Boucher summed up the articulator controversy by stating, "It must be recognized that the person operating the instrument is more important than the instrument. If dentists understand articulators and their deficiencies, they can compensate for their inherent inadequacies".

\section{REFERENCES}

1. Mitchell DL, Wilkie ND. Articulators through the years. Part II. J Prosthet Dent. 1978; 39:451-8. [DOI: 10.1016/S00223913(78)80166-8]

2. Starcke Edgar N. The history of articulators: Early attempts to reproduce mandibular movement. Part III. I Prosthodont. 2000; 9:217-22. [DOI: 10.1111/j.1532-849X.2000.00217.x]

3. SAM Catalogue 2011 [cited 10 October 2016]. Available from: www.sam-dental.de/pages/de_catalogues.html.

4. Artex System Catalogue 2011 [cited 10 October 2016]. Available from: https://www.amanngirrbach.com.

5. Protar evo 2007 [cited 10 October 2016]. Available from: www. kavo.com/uk/protarevo/dental-articulators.

6. Zarb, Bolender. Prosthodontic Treatment For The Edentulous Patient. 12th edn. St Louis: C.V. Mosby; 2004; p. 291-2.

7. Sheldon W. Essentials of complete denture prosthodontics. 2nd Indian edn. AITBS Publishers. 2009; p. 142-3

Received: 26.05 .2017 • Accepted: 08.08.2017 


\title{
Istorija artikultora - drugi deo
}

\author{
Navnit Kaur Man', Nita Pasriča ${ }^{1}$, Kavipal Sing ${ }^{2}$, Navdžot Sing Man ${ }^{3}$ \\ ${ }^{1}$ Nacionalni stomatološki fakultet i bolnica, Dera Basi, Pandžab, Indija; \\ ${ }^{2}$ Institut za stomatološke nauke i istraživanje „Sri Guru Ram Das", Amricar, Pandžab, Indija; \\ ${ }^{3}$ Katedra za konzervativnu stomatologiju i endodonciju, Čitatelj, Nacionalni stomatološki fakultet i bolnica, Dera Basi, Pandžab, Indija
}

\begin{abstract}
KRATAK SADRŽAJ
Artikulatori su instrumenti koji imaju za cilj da reprodukuju pokrete vilica. Prvi dizajni ovih instrumenta bili su pokušaji dupliranja anatomskih odnosa ili reprodukovanja funkcionalnih pokreta. Oni su jedino mogli da adekvatno reprodukuju centralnu poziciju. Kasnije su se pojavili sofisticiraniji artikulatori sa novim saznanjima o anatomiji, mandibularnim pokretima i mehaničkim principima. Tokom vremena raslo je interesovanje za artikulatore. Oni su postali podesivi i pokušali su da reprodukuju individualne pokrete vilica svakog pacijenta reprodukcijom anatomije temporomandibularnih zglobova (TMZ) i susednih struktura. Prvi deo našeg rada je razmatrao razvoj artikulatora od 18. veka do 1940. godine. Istorija artikulatora od 1940. do danas predstavljena je u ovom članku.
\end{abstract}

Ključne reči: artikulatori; instrumenti; liveni; temporomandibularni zglobovi; šarke

U ovom članku, u nastavku istorije artikulatora I, gde je opisana evolucija artikulatora počev od 16. veka, govori se o istorijskom aspektu artikulatora od 1940. godine do danas.

Artikulatori uvedeni od 1940. najpre su bili instrumenti koji samo reprodukuju propisani položaj, a onda je došlo do razvoja i nastanka potpuno podesivih artikulatora [1]. Početkom 20. veka nekoliko autora je ispitalo prirodu pokreta mandibule. Stoga, razvoj artikulatora tog vremena odražava novootkrivene ili potvrđene principe [2]. Istorijski gledano, neki aspekti kretanja vilice su se lako mehanički prenosili i reprodukovali u artikulatoru (pokret po osovini, odnos modela prema osovini, kao i kondilarni nagib). Shodno tome, ove karakteristike su se prve pojavile na instrumentima. Ostali pokreti kao što su Benetov pokret u tri dimenzije, vreme Benetovog pokreta, tačna krivina kondila i interkondilarna distanca bili su teži da se reprodukuju mehanički. Problemi u dupliciranju ovih pokreta su rešeni savremenim dizajnom instrumenta. Kroz istoriju, neki artikulatori su modifikovani, neki od njih uopšte nisu prihvaćeni od strane profesije pa su zato i nestali.

Cilj ovog rada bio je da opiše artikulatore uvedene u stomatološku praksu od 1940. do danas.

Elektronska pretraga je obavljena u okviru tri baze podataka (Science Direct, PubMed i Google Scholar) za relevantne citate. Ključne reči kao što su artikulatori, istorija i rani artikulatori korišćene su same ili u kombinaciji za pretraživanje. Korišćena je i opcija „povezanih članaka“. Na kraju, izvršena je pretraga revijalnih radova i izabrani su najvažniji citati koji se odnose na istoriju artikulatora.

\section{Modifikovani artikulator Stephen}

Artikulator Stephen (Slika 1), modifikovan 1940, jednostavan je zglobni instrument koji je imao fiksni ugao kondilarne putanje od 30 stepeni. Sličan je u dizajnu modelu iz 1921. godine, osim što su gornja i donja grana na ovom modelu duži. Podesivi šrafovi u zadnjem delu drže gornji i donji deo u fiksnom vertikalnom položaju [1].

\section{Artikulator Stephen, model P}

Dodatne karakteristike artikulatora Stephen, model P su incizalni kočić i vertikalno podešavanje visine. Još jedna verzija ovog artikulatora je proizvedena tako da sadrži fiksni incizalni nagib od 10 stepeni [1].

\section{Artikulator Fournet}

Artikulator Fournet (Slika 2) razvijen je oko 1940. godine i distribuiran od strane Dentists' Supply Co., Njujork. To je bio jednodimenzionalni artikulator koji nije imao bočne pokrete. Model gornje vilice bio je orijentisan i postavljan horizontalno pomoću (1) dva maksilarna centralna sekutića, koja su bila estetski orijentisana i naslanjala se na Špeovu krivu napred i (2) držač za montiranje, koji se uklapa u dubinu žleba i usmerava modele posteriorno [1].

\section{Artikulatori Johnson-Oglesby}

Artikulator Johnson-Oglesby je razvijen oko 1950. godine. To je mali, nepodesivi, fleksibilni artikulator. Njegova upotreba je bila ograničena, a zubne nadoknade napravljene u njemu su ponekad zahtevale veliko podešavanje na pacijentu [1].

\section{Artikulator Coble}

Ovaj artikulator razvio je oko 1950. godine Lucian G. Coble. Artikulator Coble održava centralnu relaciju i vertikalnu dimenziju, ali ne dozvoljava funkcionalne kretnje. To je osovinski artikulator u kome se gornja vilica podešava pomoću montažnog šrafa koji odgovara okluzalnoj ravni. Model donje vilice se postavlja pomoću zapisa zagrižaja [1].

\section{Artikulator Galetti}

Artikulator Galetti (Slika 3) - prvi je proizveden oko 1950. godine u Italiji. On je reklamiran početkom 1960-ih i distribuirao ga je od John O. Luongo. U ovom artikulatoru svaki model je bio mehanički fiksiran bez gipsa pomoću dva fiksna kočića spreda i jednog podesivog kočića sa zadnje strane svakog modela. Gornji 
model se mogao podešavati pomoću zglobova da bi se postigao željeni odnos gornje i donje vilice i tako ubrzalo postavljanje modela. Ovaj artikulator je imao fiksni ugao kondilarne putanje i vertikalni stoper u zadnjem delu. Nije prihvatio obrazni luk [1].

\section{Artikulator Pankey-Mann}

Artikulator Pankey-Mann (Slika 4) razvijen je 1955. godine od strane Lindsey De Pankey i Arvin W. Mann. Ovaj artikulator se sastojao od postolja koje drži platformu za model donje vilice i vertikalnog kočića koji drži dva pokretna dela. Prvi deo je bio sastavljen od horizontalnog štapa koji drži okvir obraznog luka, ima centre rotacije za merenje i presecanje na željenu veličinu. Drugi pokretni deo drži postavljeni model vilice. Korišćenjem njihovog obraznog luka za postavljanje modela donje vilice i uspostavljanje okluzalne ravni na zubima donje vilice prema sferičkoj teoriji, celokupna okluzalna ravan je uspostavljena pre bilo kakvog rada na zubima [1].

\section{Artikulator Stuart}

Artikulator Stuart (Slika 5) razvio je Charles E. Stuart 1955. godine. To je bio potpuno prilagodljiv artikulator. Gornji član artikulatora imao je dva ispupčenja sa zadnje strane koji vode dve zarubljene sfere koje se nalaze na donjem članu. Pokretno spoljno ispupčenje i sfera sa obe strane kontrolišu sve kondilarne kretnje osim Benetovog ugla i vremena pokreta, koji su kontrolisani unutrašnjim ispupčenjem i sferom. Podešavanja artikulatora su programirana pomoću pantografskih zapisa pacijenta [1].

\section{Model Hanau, $\mathrm{H} 2$ serija}

Model Hanau 96 H2 pojavio se 1958. godine. Glavna karakteristika ovog artikulatora bila je veće rastojanje između gornjeg i donjeg dela od $95 \mathrm{~mm}$ na približno $110 \mathrm{~mm}$. Pored toga, gornji član je dobio orbitalni indikator. H2-XPR, koji je jedan od modela serije $\mathrm{H} 2$, uveden je 1958. godine. Imao je identične osobine kao i drugi modeli u ovoj seriji, ali pored toga je imao proširene kondilarne osovine i podešavanje kondilarnog elementa napred-nazad. Neki drugi modeli serije $\mathrm{H} 2$ su:

(1) Model H2-O, sa dodatkom za orbitalnu indikaciju;

(2) Model H2-X, sa proširenim kondilarnim vratilom;

(3) Model H2-PR, sa kalibriranim podešavanjima za pomeranje kondila napred-nazad do $3 \mathrm{~mm}$.

Elinchbaugh je opisao adaptaciju Hanau modela H110 artikulatora, koji koristi plastični podmetač od 0,75 inča kako bi povećao visinu postolja kondila. Takođe je opisao izradu orbitalne ravni od 0,75 inča plastike koja je davala prednju referentnu tačku za nivo kondilarne ose. Ova adaptacija je učinila model $\mathrm{H}$ ekvivalentnim nekim modelima serije H2 [1].

\section{Artikulator Dentatus ARL}

Artikulator Dentatus ARL (Slika 6) prvi put je proizveden od strane A. B. Dentatusa iz Stokholma, Švedska, 1958. godine. To je bio polupodesivi artikulator tipa vratila sa ravnim kondilarnim nagibom i fiksnim interkondilarnim rastojanjem. U mehaničkom principu i dizajnu bio je sličan artikulatoru Hanau H2. Prilagodljivi mehanizam za pozicioniranje na gornjem delu omogućio je korištenje bloka koji standardizuje gornji član prema donjem članu i prenos modela sa jednog na drugi artikulator dok je isti odnos modela zadržan. Dentatus ARL je bio krut, izdržljiv instrument sa incizalnim kočićem. Produžeci kondilarne osovine omogućavali su prihvatanje obraznog luka. Benetov pokret je izračunavan iz Hanauove formule, a rotacija kondila do 40 stepeni je omogućavala njegovo podešavanje. Kao i kod artikulatora Hanau, veličinu Benetovog pokreta bilo je moguće kontrolisati, ali ne i njegovo vreme i pravac [1].

\section{Poboljšani novi prosti artikulator}

Ovaj artikulator (Slika 7) distribuiran je od strane Dentists 'Supply Co. u Njujorku 1960. godine. Ovo je poboljšana verzija artikulatora Gysi Simplex. On je koristio prosečne vrednosti pokreta. Kondilarni nagib je bio 30 stepeni, a Benetov pokret 7,5 stepeni. Incizalni tanjirić se podešavao od 0 do 30 stepeni kako bi se prilagodio različitim veličinama vertikalnog preklapanja zuba za svakog pacijenta. Imao je kočiće za zaključavanje modela kako bi osigurali maksilarne i mandibularne modele stabilne i na mestu. Montažna konzola, koja se udvostručuje kao okluzana ravan, korišćena je za proizvoljno montiranje maksilarnog modela [1].

\section{Vertikulator}

Vertikulator je razvio William Windish 1960. godine. Sastojao od dva kruta člana koja se odvajaju i zatvaraju samo linearno u vertikalnoj dimenziji. On je imao pozitivni stoper koji se zaključavao u zatvorenom položaju. Drugi model uveden je 1962. godine i bio u stanju da prihvati modele potpunih vilica [1].

\section{Artikulator Ney}

Artikulator Ney (Slika 8) dizajnirao je Anthony J. De Pietro 1962. godine. To je arkon instrument bez uređaja za zaključavanje između gornjeg i donjeg dela za centričnu poziciju. Kondilni elementi mogu se podesiti na različita interkondilarna rastojanja. Kada metalni kondilarni elementi ne prate ili dupliraju pantografske zapise, preciznije dupliranje je moguće sa prilagođenim plastičnim umecima. Tanjirić po kome se kreće incizalni kočić može biti plastični ili metalni [1].

\section{Artikulator Hanau, model 130-21}

Hanau univerzitetska serija ili model 130-21 dizajniran je da bude instrument sa podeljenim osovinama. On je imao centralno zaključavanje i mehanizam za držanje gornjeg i donjeg člana zajedno. Takođe je bio podesiv na različitim interkondilarnim rastojanjima. Kondilarni nagib i Benetove kretnje su bile ravne. Vodiči Benetove kretnje koji se bili blizu srednje linije nisu dozvoljavali trenutni pomak bočne strane. Prihvatio bi sve položaje, ali nije mogao duplirati pantografske tragove. Inicizalni kočić je bio dizajniran da nadoknađuje promene u vertikalnoj dimenziji. Bio je samoadaptivni i u obrnutom položaju [1].

\section{Artikulator Whip-Mix}

Ovaj artikulator je razvio Charles E. Stuart 1964. godine. Ovo je bio polupodesivi arkon artikulator koji je imao tri interkondi- 
larna podešavanja: mala, srednja i velika. Oni su birani pomoću obraznog luka koji koristi spoljni ušni kanal signal kao zadnji orijentir. Ovaj obrazni luk je imao je prednji vodič (nasion) za uspostavljanje prednje referentne tačke za pozicioniranje maksilarnog modela. Kondilni nagib na artikulatoru Whip-Mix je bio podesiv u odnosu na vertikalnu i horizontalnu, ali ne i na sagitalnu osu, tako da se nije mogao postaviti na sve pozicije. Kondilni nagib i Benetova kretnja su bili ravni. Vreme Benetove kretnje nije bilo određeno. Nije bilo uređaja za zaključavanje položaja, a gornji i donji delovi nisu mogli biti mehanički pričvršćeni [1].

\section{Simulator}

Simulator (Slika 9) razvio je Ernest R. Granger 1968. To je bio potpuno podesiv artikulator koji se mogao podesiti koristeći pantografske tragove, pozicijske i druge zapise. On je imao zakrivljene kondilarne putanje, ali jedinstvene karakteristike ovog artikulatora bile su kondilarna staza koja se okreće unutra, slomljena osa i mehanički element koji se sastojao od mehaničkog reprodukovanja Benetovog pokreta i Fišerovog ugla. Simulator je imao šrafove koji su omogućavali da se gornji član odvoji od donjeg člana. Incizalni kočić je bio zakrivljen [1].

\section{Artikulator Denar, model D4A}

Ovaj artikulator razvio je Niles Guichet 1963. godine. On se podešavao pomoću zapisa dobijenih pneumatski kontrolisanim pantografom iste kompanije, Denar Corp, Anaheim, Kalifornija. To je bio potpuno prilagodljiv instrument koji je koristio promenljive kondilarne nagibe koji su se mogli podešavati. Imao je određenu centralnu bravicu, ali se mogao držati i u otvorenom položaju. Zakrivljeni incizalni kočić se naslanjao na mehanički ili plastični stočić [1].

\section{Artikulator Dentatus ARO}

Artikulator Dentatus ARO je proizveo A.B. Dentatus 1971. godine. Imao je sve karakteristike Dentatus ARL plus jedinstvenu osobinu pokretne ručice koja drži model donje vilice. Univerzalni zglob i uređaj za zaključavanje koji pričvršćuju pokretnu ručicu na bazu omogućavali su pozicioniranje modela donje vilice glave bez ponovnog podešavanja. Donji član se mogao centrirati prema gornjem članu, ali kad je jednom postavljen model donje vilice u određeni položaj, artikulator ili modeli se nisu mogli menjati bez pomoći zapisa centralnog odnosa vilica [1].

\section{Artikulatori Panadent}

Panadent sistem je pokazao najnoviji pristup stomatološkim instrumentima. On je bio zasnovan na pretpostavci da je moguće klasifikovati pojedine kondilarne kretnje u grupe na osnovu bočnog pomaka. Razvijena je serija statistički odabranih trodimenzionalnih analoga pokreta kondilne ose. Artikulator Panadent je predstavljen 1978. godine. Aktuelni modeli uvedeni su 1983. godine. Glavna modifikacija u najnovijim modelima bila je mehanička brava Dynalink Panalock. Ovaj mehanizam održava gornji i donji okvir artikulatora zajedno, ali ipak omogućava njegovo otvaranje od 180 stepeni [1].

\section{Nedavni napredak SAM}

Kompaniju je osnovao 1971. godine Heinz Mack, stomatolog praktičar iz Minhena, Nemačka. Njegov anatomski ispravan instrument postao je poznat i identifikovan kao SAM (School Articulator Munich). Svi modeli su bili arkon tipovi artikulatora. SAM je razvio širok spektar modela artikulatora, uključujući SAM SE, SAM 2P, SAM 2PX i SAM 3. Ovi artikulatori pružaju tačnu funkcionalnu simulaciju pokreta donje vilice $[2,3]$.

\section{Artikulator Artex}

Ovaj artikulator je razvila kompanija GIRRBACH DENTAL GMBH i bio je naveden u FDA listi 24. maja 1995. ARTEX CN, koji je bio osnovni model, artikulator je srednjih vrednosti koji nije arkon tip. ARTEX CT je delimično podesivi artikulator srednje vrednosti u non-arkon dizajnu. Zatim je dolazio ARTEX CP, koji je bio delimično podesiv artikulator srednjih vrednosti sa super-glatkim kondilnim vodičem u arkon dizajnu. Najnoviji model bio je ARTEX CR, koji je bio potpuno prilagodljiv artikulator srednjih vrednosti u arkon dizajnu. On je omogućavao sveobuhvatna podešavanja za reprodukciju pacijentovog razmaka gornjih i donjih zuba i dinamike kretanja [4].

\section{Artikulator Protar}

Razvijen od strane kompanije KaVo početkom ovog veka. Artikulatori PROTAR (Slika 10) nudili su dobru preciznost, bili su ekonomični i laki za rukovanje. Na raspolaganju su četiri modela - PROTAR, PROTAR 3, PROTAR 5, PROTAR 7, a najnoviji model je PROTAR 9. Dimenzije PROTAR-a su 6,4" V $\times$ 6,6 " $\breve{S} \times 8$ " D, a težina 2,5 lb. PROTAR 3 ima gornji član sa zakrivljenim sagitalnim i unapred zadanim kondilnim stazama, $45^{\circ}$ horizontalnim nagibom kondilne putanje i fiksnim Benetovim uglom od $15^{\circ}$. PROTAR 5 ima gornji član identičan onom kao kod artikulatora PROTAR 3 sa izuzetkom da on ima podesivi Benetov ugao i horizontalni kondilni nagib. PROTAR 7 ima gornji deo sa podesivim sagitalnim uglom i horizontalnim kondilnim nagibom, kao i neposrednim pomicanjem u stranu i podesivim uglom pomaka. PROTAR 9 ima gornji član identičan PROTAR 7 sa podesivom protruzivnom kretnjom, distrakcijom i retruzivnom kretnjom [5].

\section{Virtuelni artikulatori}

Najnoviji napredak u svetu artikulatora bilo je uvođenje artikulatora VIRTUAL 2003. godine. Ovaj sistem ne samo da simulira temporo-mandibularne pokrete u softveru za modelovanje tako što ga pregledava na ekranu računara već je to i jedini sistem koji dozvoljava zubnom tehničaru da uzme merenja sa svog artikulatora, skenira ih i doda ove podatke u softver. Dimenzije artikulatora su verno prenesene u softver kako bi mogli virtuelno postaviti modele.

\section{ZAKLJUČAK}

Veliki broj i složenost modernih artikulatora mogu dovesti u zabludu praktičare da misle da je izbor odgovarajućeg instrumen- 
ta težak. Međutim, izbor je u velikoj meri pojednostavljen, ako se uzme u obzir koje podatke je moguće dobiti tačno, šta se očekuje od artikulatora, kao i činjenica da tehnologija artikulatora nije zamena za biološko razumevanje mastikalnog sistema [6]. Rastuće razumevanje neurofiziologije pokreta donje vilice i uticaj nekoliko morfoloških i bihevioralnih karakteristika doveli su do ideje da je svaki pacijent njegov ili njen najbolji artikulator.
Takođe, uspeh ili neuspeh finalne zubne nadoknade više zavisi od onog ko koristi artikulator nego od samog artikulatora [7].

Carl O. Boucher sumirao je kontroverzu artikulatora navodeći: „Mora se priznati da je osoba koja upravlja instrumentom važnija od instrumenta. Ako stomatolozi razumeju artikulatore i njihove nedostatke, oni mogu nadoknaditi njihove inherentne neadekvatnosti“. 